\title{
Research in the interest of children: SAJCE after five years
}

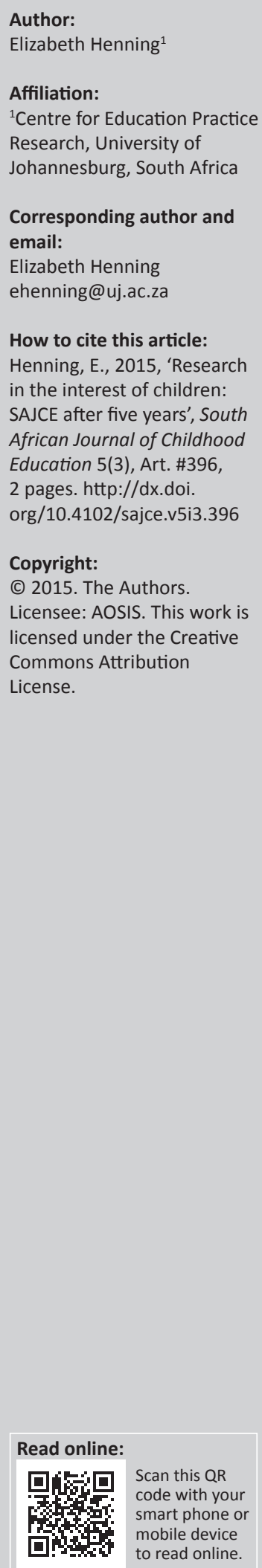

\section{Introduction}

When we put this issue together, it struck me, as it always does when we assemble an issue, that the tone of the articles have a common thread: The authors write about their research not only as social scientists, but also as advocates for children's right to a sound education. From a wide spectrum of research domains, the authors present 'usable knowledge', derived from their findings. 'Usable knowledge' is a term we adopted from the Harvard Graduate School of Education when we started research projects in the Childhood Education programme at our university. We asked ourselves at the outset of the programme in 2010, and when we were planning this journal at the same time, how our search for knowledge could ultimately be used somewhere, by someone, in the vast system. At the end of the fifth year of this journal's existence, I believe we have achieved some of our goals of usability.

Few researchers who encounter the conditions in education like we do in South Africa can afford the privilege of researching a phenomenon because it is an interesting phenomenon. Most of the research I have encountered as editor of two journals has, rather, been conducted in the interest of children and youth. The knowledge pursued in the articles that I read through the years, starting in 1997 with the journal Education as Change, have had a strong utility grounding. In this issue of the South African Journal of Child Education (SAJCE) usability of knowledge in different domains of Childhood Education is also evident.

\section{Pre-service teacher education}

In the first article author Deidre Geduld reports on her study of collegial relationships of teachers and student teachers. She found that collegial teams of teachers and Education students can promote a sensibility for inclusive education in the early grades. Her argument speaks to teacher educators, who may sometimes neglect to nurture mentoring relationships between teachers and the students who practice the craft of teaching in their classes.

Another article with a focus on pre-service teacher education highlights the difficulties of most foundation phase teacher education programmes: students enter university with an almost hostile attitude to mathematics and a low self-concept of their own knowledge. The good news that Moodley and co-authors bring for users is that the students are generally positive about their future role as mathematics teachers. This is also what Fonseca and Petersen found in their study of an online programme for the enrichment of student teachers' mathematics content knowledge. Students were motivated by the mere opportunity to increase their content knowledge. The intervention study of the online programme, run by Numeric (http:/ / www.numeric.org.za), and utilising the Khan Academy platform, shows that online learning and practice may be a good option for the future. Early grades education needs teachers who have enough good experiences in maths learning themselves in order to teach with joy and understanding.

\section{Education and its helping disciplines}

Oosthuizen, Klop and Visser contribute to usable knowledge in teacher education from the view of students of Speech-Language and Audiology therapy, classroom teachers and clinical tutors. These authors are continuing a trend in SAJCE, which started with the first issue in 2011, namely that the helping professions adjacent to education practice share their knowledge and interest in children by disseminating it in this journal. The authors emphasise transdisciplinary collaboration to form teams of support for children in need of what is known as the three-tier system of intervention: (1) the class teacher learns general skills for adaptive teaching that is applied to the whole class, (2) additional intensive help is provided in small groups and (3) for children who show signs of extreme learning difficulties, specialist support is provided, often as a one-on-one intervention with a specialist therapist. 
Swanepoel and co-authors, who are specialists in SpeechLanguage and Audiology, provide evidence of the importance of visual feedback on classroom noise levels. This is a crucial issue in South African schools, where young children have to attend to classroom talk in overcrowded and very busy classrooms. At the University of Johannesburg teaching school on the Soweto campus a programme of 'The Calm Classroom' has been implemented to create an auditory environment where noise levels had clearly been affecting behaviour, and, ultimately, also learning. It was therefore with great appreciation that we received a manuscript from a research team that is led by an esteemed researcher like De Wet Swanepoel, who has received the Presidential Award from the National Research Foundation of South Africa for his outstanding research.

\section{Leading a school's pedagogy}

The calm classroom implies, also, the calm school. The responsibility for leading and managing a school lies in the hands of the principal and his or her team. But beyond ensuring that the school is a safe learning space, principals also have to provide leadership about the curriculum and instruction. Naidoo and Petersen argue that principals have to not only know the curriculum, but also show leadership in how to deal with the demanding curriculum in South African primary schools. In the study it was found that school principals do not identify strongly with this role as leader of curriculum and pedagogy. The journal would argue that school leaders are not executives and administrators as much as mentors of their school community - serving as guide and support - for teachers from Grade R throughout the primary school.

\section{Pre-school, Grade R and the foundation phase}

Nislin and her co-authors investigated how kindergarten (Grade R) teachers see themselves and found that despite an overall sense of well-being as professionals, they felt that they are not able to address the needs of children with special educational needs. They echo what pre-school teachers generally see as a void in their own education. Certainly, in the Grade $\mathrm{R}$ classes we encounter in our research, teachers would agree with these research findings from Finland.

Streit, Kunzli David and Hildebrandt also investigated preschool learning - specifically the convergence of informal pre-school and formal education. The model they present shows how German-speaking countries search for this convergence. In this journal Henning and Dampier (2012) examined this space of liminality, suggesting that the rite of passage between a child's early learning phases needs to be considered carefully. The German model presents a feasible way to address the challenges of integration between the two phases of childhood learning where, playful learning moves into learning with play.

Ogunyemi and Ragpot interrogate the issue of 'work and play' from two countries on the African continent. Central to their discussion is the argument that a "playful" learning environment is optimal for the 'work' of learning. Conceptions of school, however, can dominate in pre-schools, something that the ECD community in South Africa is taking seriously. The study by Aronstam and Braund confirm that teachers in pre-schools and in Grade R may not fully comprehend the power of play as pedagogy.

In playful learning, it is generally assumed, children's play features as way of creating and communicating their world. When Naude investigated Grade R - 3 children's response to science classroom demonstrations, he found that their playful, inventive reactions contained multiple signs of causal reasoning in the formal disciplines of science in the school curriculum, long before they had studied the topics in biology, physics, chemistry and astronomy. Graven's article about the experiences in the maths clubs of the Eastern Cape is perhaps one of the best examples of how informal (playful) encounters with mathematics outside the school in social clubs can serve as springboard for changing dispositions. In her role as Numeracy Chair, Graven has initiated work in this 'third space' of education, following on the example of a leading Vygotskian scholar's innovations. Michael Cole's Fifth Dimension after school programme (https://www. russellsage.org/publications/fifth-dimension) has many of the characteristics of Graven's innovative development and research work.

\section{SAJCE: The next five years}

From Volume 5(3) onwards the journal will be published by AOSIS, with a new website on the Open Journals System, following with the publication of Volume 6(1) in June 2016. It is with enormous gratitude that we take leave of Reedflute Software Solutions, where our website was managed and maintained, and Sun-Media Metro, which has been the production house since the founding of the journal. Due to the growth of the work, it is no longer possible to run the management and administration of the journal in what was, essentially, a 'cottage industry' from the journal manager's desk. The Centre for Education Practice Research at the University of Johannesburg (UJ) remains the editorial home of the journal.

We will continue to publish research in the interest of children learning in the formative years.

\section{Reference}

Henning, E. \& Dampier, G., 2012, 'Linguistic liminality in the early years of school: Urban South African children "betwixt and between" languages of learning, South African Journal of Childhood Education 2(2), 100-119. 